Article

\title{
Sustainable Green Product Adoption Test Using Logistic Regression: Comparison of Glass and Electronic Products
}

\author{
Lan-Lan Wan ${ }^{1}$ and Hong-Youl $\mathrm{Ha}^{2, *(1)}$ \\ 1 School of Economics and Management, Shanghai University of Political Science and Law, \\ Shanghai 201602, China; wanlanlan@shupl.edu.cn \\ 2 School of Social Science, Dongguk University, Seoul 04620, Korea \\ * Correspondence: hyha@dongguk.edu
}

Citation: Wan, L.-L.; Ha, H.-Y. Sustainable Green Product Adoption Test Using Logistic Regression: Comparison of Glass and Electronic Products. Sustainability 2021, 13, 5084 https://doi.org/10.3390/su13095084

Academic Editor: Riccardo Testa

Received: 24 March 2021

Accepted: 28 April 2021

Published: 1 May 2021

Publisher's Note: MDPI stays neutral with regard to jurisdictional claims in published maps and institutional affiliations.

Copyright: (c) 2021 by the authors. Licensee MDPI, Basel, Switzerland. This article is an open access article distributed under the terms and conditions of the Creative Commons Attribution (CC BY) license (https:// creativecommons.org/licenses/by/ $4.0 /)$.

\begin{abstract}
Marketing literature emphasizes the importance of green product adoption for environmental sustainability. However, consumers' evaluations of the key factors (for adopting green products) differ in critical ways. Drawing on a consumer-marketing interface, this study uses a binary logit model to investigate how consumers adopt two different types of products (e.g., glass and electronic). The results show that the impacts of the twelve factors behind consumer adoption of green products vary widely between glass and electronic products. Specifically, the analysis identifies four factors (eco-labeling, peer groups, cultural values, and environmental awareness) that have no influence on consumer adoption intentions. It also shows that males are more likely to have positive adoption intentions than females for both glass and electronic products. The authors conclude this paper by discussing the implications of these important findings for research and practice.
\end{abstract}

Keywords: green product; adoption factors; logistic regression model; product comparison

\section{Introduction}

Since Jansson [1] revealed the characteristics of consumer adoption in the context of innovate new products, scholars have advocated extending this research into the realm of energy-efficient or green products. Several recent studies [2-4] seeking to reveal why consumers adopt green products have focused on different contexts, further enriching our understanding of the key factors that influence consumers' decisions to adopt specific products. Hazen et al. [5] also pointed out that consumer adoption of green products may vary based on product types and industry sectors, indicating that the factors may also vary.

While consumers explore green products, there are critical gaps that may not be linked to the key factors researchers have identified [6]. More specifically, such gaps usually occur when researchers identify important factors or barriers that affect consumers' attitudes towards green products $[4,6,7]$, but discrepancy exist between consumers' attitudes and their actual thoughts. That is, how consumer adoption of green products differs with regard to both factors and product types remains unclear. To extend this research stream, we demonstrate that there may be systematic and significant differences in the factors that affect consumer adoption of green products. More specifically, green product-specific factors (for example, environmental attitudes, tax credits, eco-labeling, financial incentives, green advertisements, etc.) may influence consumer choice behavior regarding green products [2,3,8-11]. This is a fundamental problem, since overlooking these influential factors might hinder or delay successful adoption of green products. Likewise, we lack an empirical understanding of the impact of green product factors on the choices consumers make.

Another key concern is product type, which influences whether consumers interested in green products recognize that they have a special need to actually purchase or adopt a given product [1]. Product type allows consumers to further identify their favorite benefits, rather than simply adopting specific products that have no green product information. For 
example, if a consumer needs a specific green product (i.e., an energy-efficient lightbulb) regarding which extensive information is available, he/she will have no difficulty adopting the product. On the other hand, a consumer who knows nothing about a highly efficient energy-saving glass will seek more information during the adoption process. While prior studies have employed similar approaches $[12,13]$, data-based answers remain insufficient. In line with these observations, our research questions are as follows:

- To what degree do product types and factors influence consumer adoption of green products?

- What are the fundamental differences between the green production adoption factors identified in previous research?

- To what degree do consumer characteristics influence consumer adoption of green products?

By examining the differences between electronic and glass products, we seek to answer these questions and to provide insights that will help the green product industry achieve a sustainable, innovative, and clean environment. Since green (e.g., energy-efficient) electronic products are characterized by easy user access and fewer sellers distribute glass products, the factors that affect consumers' adoption of such products differ fundamentally. Consumer adoption of green products varies based on product type and is influenced by consumer characteristics and other factors. In particular, we demonstrate that two additional factors-financial incentives and product knowledge-may combine with existing factors to determine key differences in outcomes.

As previously noted in this study, we specifically focus on glass and electronic products as types of energy-efficient products. For example, air-heating and air-conditioning are the major energy-consuming components in the heating- and cooling-dominated houses, buildings, and accommodations [14]. Similarly, the impact of electronic products, considered a major environmental factor, mainly depends on the amount of energy consumed in the various available approaches [15] because these products are closely related to the lives of consumers.

This study, therefore, makes two key contributions. First, unlike previous studies, we examine the specific factors that determine how consumers choose green products. Specifically, we focus on twelve factors and gender. Theoretically, these factors represent significant determinants of green product adoption or selection; specifically, their impacts may differ from selection procedures by framing consumers' perceptions of green product adoption [16]. Relative adoption can frame consumers' perceptions of critical green product factors. It thus affects subsequent selection decisions.

Second, our findings contribute to emerging green product literature, which largely overlooks highly involved green products and focuses primarily on gender-based differences, such as preference and choice [17]. Our findings should prove useful for green manufacturing firms by giving them a better understanding of the different impacts of key factors and gender differences, and thereby helping them identify effective ways to attract potential consumers.

The remainder of this study is organized as follows. First, we review related research and provide detailed rationales for our research model and hypotheses. We then describe the data collection and data analysis techniques we use. After reporting the hypotheses testing result, we discuss the theoretical and practical implications of our findings, the limitations of our study, and directions for future research.

\section{Research Background}

Neither the escalating problem of global greenhouse emissions nor the expectation that the resulting changes to the climate will have serious impacts on the planet in the coming years are new. From the environmental perspective, the UK government [18] contends that "there is still time to avoid the worst impacts of climate change, if we act now and act internationally". Proponents of this line of argument maintain that all stakeholders must participate in addressing the challenge together. While the consumption of natural 
energy is a critical environmental issue for governments and consumers, it offers marketers an economic opportunity [19]. Furthermore, because many consumers are still unfamiliar with green products, research examining the diffusion of new innovative green products is urgently needed [20].

Motivated by these concerns, global energy-efficient or environment-related research fundamentally focuses on social and green consumerism [4]. To better understand the adoption of green products, in this study, we consider why consumers may refrain from adopting green products. In so doing, we aim to help green product developers understand the factors that influence the adoption of these products $[4,21]$.

Nath et al.'s quantitative study [4] provides a useful framework for understanding consumer adoption of green products. It identifies five levels of factors that affect such adoption: environmental attitudes (defined as beliefs about the consequences (i.e., atmospheric pollution and water pollution) of environmental conditions for the planet) and perceived consumer effectiveness (level 1); tax credits, eco labeling, peer groups, and cultural values (level 2); environmental awareness (level 3); legal enforcement and green advertisements (level 4); high and increasing levels of education (level 5). While the meaning of the term "cultural values" may differ between national cultures, organizational cultures, or professional cultures. In this study, we define cultural values as individual beliefs about the shared conceptions of what is desirable in given cultural ecosystems.

Level 1 indicates that environmental attitudes play a significant role in increasing people's participation in environmental movements. Level 2 identifies mechanisms that help people develop favorable attitudes toward energy efficiency and environmental sustainability. Level 3 demonstrates that consumer awareness increases people's sensitivity toward environmental protection. Level 4 highlights the importance of eliciting sustainable behavior from consumers. Finally, Level 5 is considered the most important tool for spreading messages regarding environmental sustainability [4]. All five levels include important criteria for consumer adoption of sustainability.

We draw on the theory of planned behavior (TPB) [22] to support Level 1 as a theoretical starting point for adopting green products. TRA is particularly effective for conducting psychological and cognitive evaluations in the context of consumer decisionmaking [23]. When our proposed model optimizes the possible relationship between intentions and its determinants, it indicates that consumers' green product adoption intentions can be complex.

In this study, perceived consumer effectiveness is the main predictor of green product adoption as a behavioral enabler [4,24]. This is because perceived consumer effectiveness is considered a type of consumer attitude toward green products [25]. While this may help increase consumer participation or change environmental attitudes, some additional factors can be drawn from previous work.

Table 1 summarizes important studies in the green product adoption literature related to the factors that play key roles in the adoption of green products and adds two factors along with theoretical justifications for the selection of these factors. As Table 1 shows, while several studies have described the key factors that impact green product adoption [24,26-28], studies seeking to develop a complete understanding of the main factors behind green product adoption remain scarce [4,29]. While Nath and colleagues [4] identified a relatively important set of key factors, additional factors require attention in this study.

This study adds the two factors of financial incentives [29] and product knowledge [27,28], which play vital roles in increasing the adoption of green products. For instance, tax exemptions or reductions decrease purchase prices and encourage consumer adoption. From a traditional marketing perspective, consumers and product agencies force firms to cut prices or provide non-financial benefits. Another example is knowledge about green products that positively affects consumer attitudes regarding the adoption of such products. Product knowledge is fundamentally important to improving consumer attitudes 
towards green products [30], and consumer decision-making literature has overlooked this construct.

Table 1. Consumer Green Product Adoption and Its Key Factors.

\begin{tabular}{|c|c|c|c|c|c|c|c|}
\hline Key Factors & $\begin{array}{c}\text { Gallagher and } \\
\text { Muehlegger } \\
\text { (2011) }\end{array}$ & $\begin{array}{l}\text { Gerpott and } \\
\text { Mahmudova } \\
\qquad(2010)\end{array}$ & $\begin{array}{l}\text { Ha and Janda } \\
\text { (2012) }\end{array}$ & $\begin{array}{c}\text { Lai } \\
(1991)\end{array}$ & $\begin{array}{l}\text { Lynne and } \\
\text { Rola (1988) }\end{array}$ & $\begin{array}{l}\text { Nath et al. } \\
\text { (2013) }\end{array}$ & Our Study \\
\hline $\begin{array}{c}\text { Environmental } \\
\text { attitudes }\end{array}$ & $\sqrt{ }$ & $\sqrt{ }$ & $\sqrt{ }$ & & $\sqrt{ }$ & $\sqrt{ }$ & $\sqrt{ }$ \\
\hline Consumer effectiveness & & & & & $\sqrt{ }$ & $\sqrt{ }$ & $\sqrt{ }$ \\
\hline Tax credits & $\sqrt{ }$ & & & & & $\sqrt{ }$ & $\sqrt{ }$ \\
\hline Eco labeling & & & & & & $\sqrt{ }$ & $\sqrt{ }$ \\
\hline Peer groups & & & & & & $\sqrt{ }$ & $\sqrt{ }$ \\
\hline Cultural values & & & & & $\sqrt{ }$ & $\sqrt{ }$ & $\sqrt{ }$ \\
\hline $\begin{array}{c}\text { Environmental } \\
\text { awareness }\end{array}$ & $\sqrt{ }$ & & & & & $\sqrt{ }$ & $\sqrt{ }$ \\
\hline Legal enforcements & & & & & & $\sqrt{ }$ & $\sqrt{ }$ \\
\hline Green advertisements & & & & & & $\sqrt{ }$ & $\sqrt{ }$ \\
\hline Education & & & & & & $\sqrt{ }$ & $\sqrt{ }$ \\
\hline Financial incentives & $\sqrt{ }$ & $\sqrt{ }$ & $\sqrt{ }$ & & & & $\sqrt{ }$ \\
\hline Product knowledge & & $\sqrt{ }$ & $\sqrt{ }$ & $\sqrt{ }$ & & & $\sqrt{ }$ \\
\hline
\end{tabular}

Meanwhile, this study excludes the green product attributes that affect consumer purchasing behaviors. Since these attributes exert a significant influence on consumer product choices, they encourage firms to develop new products [31]. However, green product attributes are closely related to knowledge about green products. Furthermore, consumers are likely to focus on financial incentives and environmental protection claims [32]. In this study, we deal with the latter using similar factors.

Finally, this study also focuses on gender as a key adoption variable. Gender is regarded as an important socio-demographic factor, but relatively few studies have considered green consumer profiles [33]. Prior studies have mainly focused on gender differences resulting from different socialization processes [34]. According to gender socialization theory, men and women go through different socialization process beginning in childhood and, in turn, develop different social expectations and value evaluations [35]. For example, because female consumers are socialized to be more detail-oriented, specific, and helpful in care-giving roles than male consumers [36], they have stronger environmental concerns than male consumers [37]. Other studies have also shown that female consumers' adoption of green products is primarily driven by key prediction factors such as self-awareness and economic conditions [38]. Improving the efficiency of green product adoption requires a better understanding of gender differences because men and women have different expectations for green products.

\section{Research Modeling}

We chose a binary logit model to analyze consumer choice behavior. The framework for estimating green product adoption uses a binary-dependent variable and is based on the threshold theory for decision making [39]. The theory demonstrates that decisions are made after stimuli strength increases beyond consumers' reaction thresholds [40]. More specifically, when considering green products, consumers must make decisions about whether or not they consider certain stimuli satisfactory. If satisfied, they can make decisions about the given products.

This study builds a binary logit model for the adoption of green products in which the dependent variable $Y$ (consumer adoption intentions) is a binary random variable that assumes the values zero and one [39]. This is likely to solve the probability that if the alternative $i$ (= consumer adoption intentions) is chosen, the probability that $j$ (= consumer 
non-adoption intentions) is chosen is equal to $1-P_{k}(i)$. Thus, we propose the following binary logit model:

$$
\operatorname{Prob}(y=i)=\frac{\exp \left(\alpha+\beta_{1} \alpha_{1}+\ldots+\beta_{k} \alpha_{k}\right)}{1+\exp \left(\alpha+\beta_{1} \alpha_{1}+\ldots+\beta_{k} \alpha_{k}\right)}
$$

where: (1)

$\beta$ is the vector of parameters associated with the explanatory variables and $\alpha_{k}$ is the vector of green product adoption variables [41]. Specifically, these are the values of those variables expected or experienced by consumer $k$ in terms of the adoption of green products.

$$
\operatorname{Prob}(y=i)=\frac{1}{1+\exp \left\{-\left(\alpha+\beta_{1} \alpha_{1}+\ldots+\beta_{k} \alpha_{k}\right)\right\}}
$$

In Equations (1) and (2),

Probi $=$ probability of choosing consumer adoption intentions $i$;

$\mathrm{X} 1$ = environmental attitudes; $\mathrm{X} 2=$ perceived consumer effectiveness,

$\mathrm{X} 3=$ tax credits; $\mathrm{X} 4=$ eco labeling; $\mathrm{X} 5=$ peer groups; $\mathrm{X} 6$ = cultural values,

$\mathrm{X} 7=$ environmental awareness,

$\mathrm{X} 8$ = legal enforcement; $\mathrm{X} 9$ = green advertisements,

$\mathrm{X} 10=$ high or increasing level of education,

$\mathrm{X} 11$ = financial incentive; $\mathrm{X} 12$ = product knowledge; $\mathrm{X} 13$ = gender.

The model that transforms probability (Equation (2)) into logit is as follows:

$$
\frac{\operatorname{Prob}(y=i)}{1-\operatorname{Prob}(y=i)}=\ln \left(\frac{\pi_{i}}{1-\pi_{i}}\right)=\alpha+\beta_{1} \alpha_{1}+\beta_{2} \alpha_{2}+\ldots+\beta_{k} \alpha_{k}
$$

where, $\pi_{i}$ indicates the probability of choosing $i$ (consumer adoption intentions); $\pi_{i} /\left(1-\pi_{i}\right)$ is the probability of choosing $i$ against the probability of choosing alternative $j$, if the independent variables are given [42].

Since this study uses logistic regression, we show our proposal model. As previously mentioned, our primary focus in this study is to identify the key factors that impact consumers' adoption of green products. We hypothesize that twelve factors have direct effects on consumer decision making regarding green products. We also examine which gender has a more significant impact on the adoption of green products. In particular, we incorporate the factors in Nath and colleagues' five levels of green product adoption [4] and three additional factors into the model.

Consistent with the theory of reasoned action (TRA), which suggests that individual behavior is determined by their behavioral intention (defined as a function of attitude toward the behavior and subjective norm [22]), we argue that consumers' green product adoptions and responses to environmental appeals are a function of their attitudes [4]. The TRA helps predict eco-friendly product adoption behavior, since consumers engage in behaviors to achieve desired outcomes [27]. In line with our modeling, we hypothesize the following relationships:

Hypothesis 1 (H1). Environmental attitudes positively influence green product adoption decision making.

Hypothesis 2 (H2). Perceived consumer effectiveness positively influences green product adoption decision making.

Hypothesis 3 (H3). Tax credits positively influence green product adoption decision making.

Hypothesis 4 (H4). Eco labeling positively influences green product adoption decision making.

Hypothesis 5 (H5). Peer groups positively influence green product adoption decision making.

Hypothesis 6 (H6). Cultural values positively influence green product adoption decision making. 
Hypothesis 7 (H7). Environmental awareness positively influences green product adoption decision making.

Hypothesis 8 (H8). Legal enforcement positively influences green product adoption decision making.

Hypothesis 9 (H9). Green advertisements positively influence green product adoption decision making.

Hypothesis 10 (H10). High or increasing levels of education positively influence green product adoption decision making.

Hypothesis 11 (H11). Financial incentives positively influence green product adoption decision making.

Hypothesis 12 (H12). Product knowledge positively influences green product adoption decision making.

Hypothesis 13 (H13). Female consumers are more willing to adopt green products than male consumers.

\section{Methodology}

\subsection{Data Collection}

We designed a survey during the summer of 2019 in South Korea. As meeting all consumers criteria in the survey proved difficult (since glass and electronic products differ), we contacted individuals from the two product groups separately. We chose these two product types because it enabled consumers using both product types to experience them both.

As previously noted, our target population was consumers with experience of one of the two selected green products. We used an online survey of 600 randomly selected consumers interested in green products, including glass and electronic products. We submitted the questionnaires randomly to an online panel of participants who had bought at least one green product. In other words, we used a stratified random sampling technique to select the respondents. A professional online research firm with extensive panel profiles administered the survey. E-mails and text messages were distributed to invite these selected panels to participate in the survey. To identify response profiles, the firm checked the product type (energy-efficient or green, glass versus electronic).

Of the 557 responses checked for potentially missing items and untrustworthy responses, 539 (response rate: $89.8 \%$ ) were usable questionnaires (glass: 280 vs. electronic: 259). Our sample size was adequate because researchers usually need to obtain at least ten times as many subjects as variables. The glass product consumer group included 159 male (56.7\%) and 121 female (43.3\%) participants, ranging in age from 21 to 58 years with a mean age of 42.5 years $(\mathrm{SD}=6.38)$. Meanwhile, the electronic product consumer group included 136 male (52.5\%) and 123 female (47.5\%) participants, ranging in age from 19 to 56 years with a mean age of 39.2 years $(\mathrm{SD}=6.83)$. Approximately 81 percent of survey participants had a college or university-level education, and 75 percent had average monthly household incomes over USD 4000, which closely aligned with the median Korean monthly household income [43].

\subsection{Measures}

We adapted scales from existing measures to suit the context of this study. We measured environmental attitudes, perceived consumer effectiveness, tax credits, eco labeling, peer groups, cultural values, environmental awareness, legal enforcement, green advertisements, and high or increasing levels of education using single items from Ellen et al. [44] and Nath et al. [4]. Meanwhile, we measured financial incentives using a single item from Gallagher and Muehlegger [29] and product knowledge using single item from Ha and Janda [27]. We used 5-point Likert scales ranging from "strongly agree (or excellent)" 
to "strongly disagree (or poor)" to measure the twelve factors. To measure the dependent variable (consumer green product adoption intentions), we used a categorical scale. Tables 2 and 3 (see Appendix A) present the relevant statistics.

Table 2. Variable definition and sample statistics.

\begin{tabular}{|c|c|c|c|}
\hline \multirow{2}{*}{ Variable } & \multirow{2}{*}{ Definition } & Glass Product & Electronic Product \\
\hline & & Mean (S.D) & Mean (S.D) \\
\hline$y$ & $=0$, consumer adoption intentions; 1 , otherwise & $0.64(0.45)$ & $0.79(0.42)$ \\
\hline$x 1$ & $=1$, strongly agree; 5 , strongly disagree (5-Likert) & $3.41(1.03)$ & $3.29(1.14)$ \\
\hline$x 2$ & $=1$, strongly agree; 5 , strongly disagree (5-Likert) & $3.09(1.13)$ & $3.14(1.26)$ \\
\hline$x 3$ & $=1$, strongly agree; 5 , strongly disagree (5-Likert) & $3.27(1.32)$ & $3.06(1.14)$ \\
\hline$x 4$ & $=1$, strongly agree; 5 , strongly disagree (5-Likert) & $2.93(1.09)$ & $2.88(1.20)$ \\
\hline$x 5$ & $=1$, strongly agree; 5 , strongly disagree (5-Likert) & $2.82(1.16)$ & $2.75(1.07)$ \\
\hline$x 6$ & $=1$, strongly agree; 5 , strongly disagree (5-Likert) & $2.46(1.08)$ & $2.43(1.05)$ \\
\hline$x 7$ & $=1$, strongly agree; 5 , strongly disagree (5-Likert) & $2.96(1.17)$ & $2.91(1.09)$ \\
\hline$x 8$ & $=1$, strongly agree; 5 , strongly disagree (5-Likert) & $2.41(1.02)$ & $2.45(1.06)$ \\
\hline$x 9$ & $=1$, strongly agree; 5 , strongly disagree (5-Likert) & $2.68(0.97)$ & $2.71(1.07)$ \\
\hline$x 10$ & $=1$, strongly agree; 5 , strongly disagree (5-Likert) & $2.53(1.18)$ & $2.59(1.14)$ \\
\hline$x 11$ & $=1$, strongly agree; 5 , strongly disagree (5-Likert) & $2.16(0.89)$ & $1.94(0.95)$ \\
\hline$x 12$ & $=1$, excellent; 5 , poor (5-Likert) & $2.77(1.14)$ & $2.65(1.26)$ \\
\hline SEX & $=0$, male; 1 , female & & \\
\hline
\end{tabular}

Note: Logistic regression functions better with categorical data than continuous data; however, it accepts Likert scale-based data.

Table 3. Binary logit estimates for glass and electronic products.

\begin{tabular}{|c|c|c|c|c|c|c|c|c|c|c|}
\hline \multirow{2}{*}{ Parameter } & \multicolumn{2}{|c|}{ Predicted Prob. } & \multicolumn{2}{|c|}{$\beta$} & \multicolumn{2}{|c|}{ Wald } & \multicolumn{2}{|c|}{ Sig. } & \multicolumn{2}{|c|}{$\operatorname{EXP}(\beta)$} \\
\hline & GL & EL & GL & EL & GL & EL & GL & EL & GL & EL \\
\hline & 88.9 & 91.1 & & & & & & & & \\
\hline Intercept & & & -17.265 & -22.587 & 43.808 & 33.456 & 0.000 & 0.000 & 0.000 & 0.000 \\
\hline Environmental attitudes & & & $2.245^{* *}$ & 0.198 & 33.991 & 1.268 & 0.000 & 0.260 & 9.438 & 1.489 \\
\hline $\begin{array}{c}\text { Perceived consumer } \\
\text { effectiveness }\end{array}$ & & & -0.004 & $0.584 *$ & 0.000 & 3.286 & 0.988 & 0.044 & 0.996 & 1.906 \\
\hline Tax credits & & & $1.968^{* *}$ & 0.216 & 28.328 & 0.620 & 0.000 & 0.431 & 7.122 & 1.241 \\
\hline Eco labeling & & & -0.143 & -0.135 & 0.266 & 0.700 & 0.606 & 0.603 & 0.867 & 0.729 \\
\hline Peer groups & & & 0.019 & 0.182 & 0.003 & 1.245 & 0.956 & 0.571 & 0.981 & 1.522 \\
\hline Cultural values & & & -0.159 & -0.041 & 0.290 & 0.019 & 0.590 & 0.889 & 0.853 & 0.960 \\
\hline Environmental awareness & & & 0.174 & 0.160 & 0.366 & 0.260 & 0.545 & 0.640 & 1.190 & 0.853 \\
\hline Legal enforcement & & & 0.099 & $2.334^{* *}$ & 0.111 & 21.484 & 0.739 & 0.000 & 1.104 & 10.317 \\
\hline Green advertisements & & & 0.312 & $0.713 *$ & 1.181 & 4.841 & 0.277 & 0.028 & 0.732 & 2.040 \\
\hline $\begin{array}{c}\text { High or increasing level of } \\
\text { education }\end{array}$ & & & 0.189 & $0.322 *$ & 0.527 & 1.069 & 0.468 & 0.050 & 1.207 & 1.380 \\
\hline Financial incentives & & & $0.772 *$ & $0.555 *$ & 4.861 & 3.021 & 0.027 & 0.047 & 2.165 & 1.794 \\
\hline Product knowledge & & & 0.401 & $2.428 * *$ & 2.745 & 34.400 & 0.098 & 0.000 & 1.494 & 11.336 \\
\hline $\operatorname{Sex}(1)$ & & & $-1.002 *$ & $-1.234^{*}$ & 3.802 & 4.918 & 0.050 & 0.027 & 0.367 & 0.291 \\
\hline$x^{2}$ & 248.789 & 244.827 & & & & & & & & \\
\hline$-2 \mathrm{LL}$ & 139.145 & 114.189 & & & & & & & & \\
\hline Cox and Snell $R^{2}$ & 0.392 & 0.508 & & & & & & & & \\
\hline
\end{tabular}

Note: ${ }^{*}, p<0.05 ;{ }^{* *}, p<0.01 ; \mathrm{GL}=$ Glass product; $\mathrm{EL}=$ Electronic product.

We conceptualized the study's key variables as follows. Environmental attitudes are beliefs and behavioral intentions that individuals hold regarding global environmental conditions. Perceived consumer effectiveness refers to individuals' subjective judgments of consumers' influence over environmental problems. Tax credit refers to a monetary incentive (by the government or local government) for making more eco-friendly product purchases. Peer group is the level of peer group opinion associated with green products. Cultural value is the socially accepted way of assigning value to global protection. Environmental awareness refers to consumers' willingness to pay for environmental products 
and engage in robust environmental activism. Legal enforcement refers government regulations that force people to protect the global environment. Green advertisements are marketing communications that promote green products based on their environmental attributes. High levels of education enhance positive environmental behaviors. Financial incentives are the financial benefits derived from purchasing green products. Finally, product knowledge refers to the ability to process (or evaluate) product attribute information.

Meanwhile, we sought to reduce common method bias by using single-item measures. Although Harman's single-factor test has been widely used to test for common method bias [45], it was difficult to apply with all single-item measures (e.g., because of difficulties in scale reliability and validity with single-item measures). However, researchers have also pointed out that single-item measures are acceptable when constructs are concrete [46] and when constructs minimize respondent burden [47]. This suggests that our approach may reduce any repercussions of potential bias [48].

\section{Empirical Findings}

Table 3 shows the model estimates for the glass and electronic products in terms of the twelve factors most relevant for further analysis in this study. Considerable differences exist between the two products and between gender groups, and these differences, in turn, highlight the factors that green product marketers should or should not seek to manage to facilitate product adoption.

Table 3 shows the -2 LL and Chi-square $\left(\chi^{2}\right)$ values, which represent the goodnessof-fit of the proposed models (glass product: $\chi^{2}=248.789,-2 \mathrm{LL}=139.145, p<0.05$ vs. electronic product: $\left.\chi^{2}=244.827,-2 \mathrm{LL}=114.189, p<0.05\right)$. As the model fit gets better, -2 LL approaches 0 . As the model fit gets worse, -2 LL increases. The results show that the model fit of electronic products is superior to that of glass products.

The predicted probabilities also proved acceptable (glass: $88.9 \%$ vs. electronic product: $91.1 \%$ ). The model's explanatory power using Cox and Snell $R^{2}$ varied between glass and electronic products. More specially, the explanatory power of electronic products $\left(R^{2}=0.508\right)$ was higher than that of glass products $\left(R^{2}=0.392\right)$.

Interestingly, the effects of the twelve factors on consumer adoption intentions varied significantly for the two product types. For glass products, environmental attitudes (Wald $=33.991, p<0.01$ ), tax credits (Wald $=28.328, p<0.01$ ), and financial incentives (Wald $=4.861, p<0.05$ ) significantly influenced consumer adoption intentions; meanwhile, for electronic products, six factors (perceived consumer effectiveness, legal enforcement, green advertisements, high or increasing levels of education, financial incentives, and product knowledge) had significant effects on consumer adoption intentions.

$\operatorname{Exp}(\beta)$ is the odds ratio corresponding to a one-unit change in measurement variables; we checked the $\operatorname{Exp}(\beta)$ values between the two product types. For glass products, environmental attitudes $(\operatorname{Exp}(2.245)=9.438)$ showed the highest rate of increase among all factors. If we controlled the value of the other eleven factors under the same conditions and environmental attitudes then increased by one unit, the probability of consumer adoption intentions would increase 9.438 times. For electronic products, product knowledge (Exp $(2.428)=11.336)$ showed the highest rate of increase among all factors. A one-unit change in the product knowledge factor under the same conditions would increase the probability of consumer adoption intentions 11.336 times more than the probability of consumer non-adoption intentions.

We found gender differences for both products. Negative significances (glass product: $\beta=-1.002$; electronic product: $\beta=-1.234$ ) indicated that males are more likely than females to adopt green products in both product categories. These results suggest that male and female consumers differ significantly in their adoption of green products.

Meanwhile, the fact that not all the factors were statistically significant pointed to differences and similarities between the two product types. While three factors (environmental attitudes, tax credits, and financial incentives) were significant for the glass product, six factors (perceived consumer effectiveness, legal enforcement, green advertisements, 
high levels of education, financial incentives, and product knowledge) were significant for the electronic product. Thus, only financial incentives had a significant impact on consumers' decisions regarding green products in both product categories. The finding shows that consumers value financial incentives across product types when adopting green products.

Furthermore, we proposed 12 factors for green product adoption from Level 1 to Level 5 (including two additional factors); however, the three Level 2 factors (eco-labeling, peer groups, and cultural values) and one Level 3 factor (environmental awareness) proved insignificant for both product categories. Although studies of green products highlight the importance of the proposed factors, we conclude that not all of these factors are significant in the Korean green product adoption context.

\section{Discussion}

This paper contributes to environmental marketing literature by investigating the effects of twelve factors on consumer adoption intentions regarding two energy-efficient products and by examining the respective genders of the consumers purchasing these products. The study had three main objectives. First, we aimed to understand the different effects of the twelve selected factors on consumers' adoption of energy-efficient products. Second, we investigated the fundamental differences among green products adoption factors identified in previous research. Finally, we examined how gender impacted the effects of these factors.

Regarding our hypotheses, the results showed that financial incentives (H11) and gender (H13) play significant roles in green product adoption in both product categories. Four hypotheses (eco-labeling, peer groups, cultural values, and environmental awareness: H4-H7) were validated for both product categories. Environmental attitudes (H1) and tax credit (H3) play an important role in the adoption of green products. Meanwhile, the analysis showed that legal enforcement (H8), green advertisements (H9), a high level of education (H10), and product knowledge (H12) play significant roles in the adoption of green electronic products. Thus, we found similarities and differences in the green product adoption between product types. Although the TRA is useful for predicting users behaviors toward environmentally friendly products [27], the theory must be applied carefully because not all consumers consider the proposed factors. In addition, consumer adoption behaviors vary across different product categories.

\subsection{Theoretical Implications}

First, although Nath and colleagues [4] identified five levels of consumer green product adoption, the current findings show that these factors have different effects on consumer adoption. Thus, our findings regarding these factors in the context of Korean green products do not completely align with their contention that they influence consumer adoption of green products. Indeed, we found significant differences between the two product types. Environmental attitudes and tax credits play important roles in enhancing consumer intentions to adopt glass products, whereas legal enforcement and product knowledge tend to increase consumer intentions to adopt electronic products. Interestingly, we find that perceived consumer effectiveness, high or increasing levels of education, and green advertisements only significantly influence consumer intentions to adopt electronic products.

Second, we find that financial incentives comprise the most common and influential factor in consumer adoption of green products in the two selected product categories. Given the twelve factors proposed by Nath and colleagues [4], we must be cautious in drawing conclusions from these empirical results which specifically focus on two product types because other factors (such as social endorsement of green product use, and attitudes toward environmental protection issues) might exert outsized impacts on the possibility of green product adoption. Nevertheless, our findings regarding the impact of financial incentives in the context of these two product types on consumer adoption of green products indicates that theoretical and practical studies should not overlook the 
importance of the financial incentives. In particular, the tax credits used in green product studies $[4,49,50]$ may not fully reflect consumer desire to adopt green products. Thus, as both Coad et al. [51] and Gerpott and Mahmudova [26] pointed out, developing financial incentives that balance or embrace other monetary incentives may be necessary to test the similarities and differences between our findings and those of previous studies.

Third, from the socio-demographic perspective, our empirical findings regarding gender complement the mainly contradictory results of existing research. For example, researchers have pointed out that consumer characteristics are no longer marginal issues [52,53]. Even though the notion that females are more concerned about environmental protection than males is commonly accepted $[54,55]$, studies have not yet produced significant indicative results regarding gender. This study adds empirical evidence obtained using a binary logic model regarding the impact of gender on the likelihood of green product adoption. Overall, our finding that males are more likely to adopt green products than females suggests a strong link between environmental concern and green product adoption that has found an insignificant correlation.

Finally, we find that four factors do not influence consumer adoption intentions at all: eco labeling, peer groups, cultural values, and environmental awareness. This finding indicates that these factors are not directly related to consumer choice behavior in the green product adoption context, suggesting that implementing comprehensive environmental strategies will require a better understanding of consumer green product adoption [56].

\subsection{Managerial Implications}

This study's practical findings regarding green product adoption suggest that ecolabeling is often ineffective. In particular, both glass and electronic firms may encounter difficulties because consumers have unfavorable attitudes about eco-labeling. This issue warrants attention because the occurrence of eco-labeling failure diminishes the possibility of green product adoption at least in the Korean green product context. This implies, first of all, that managers should emphasize the environmental effects of eco-labeling (e.g., this glass reduces carbon emission by a minimum of $90 \%$ compared to standard types of glass).

Firms generally prefer gender difference strategies to penetrate their new products along with other existing products. While Chen and Chai [57] reported no significant gender differences, most studies have encouraged the use of gender differences to facilitate green product adoption for selected genders. Our results suggest that male consumers tend to engage in positive behaviors if financially incentivized to do so. The financial benefits of green product adoption must be weighed against the potential avoidance of female consumers.

\section{Conclusions}

This study highlights a discrepancy between consumers' attitudes and actual thoughts in the green product adoption context. Focusing on glass and electronic products because they tend to be energy-efficient, it identifies systematic and significant differences between the factors that affect consumer adoption of green products. Specifically, the analysis reveals that the 12 factors that affect consumer adoption of green products vary between glass and electronic products and that that male consumers are more likely than female consumers to show positive adoption intentions for both glass and electronic products. Meanwhile, the study also identifies four factors (eco-labeling, peer groups, cultural values, and environmental awareness) that do not influence consumer adoption intentions. In addition, it shows that not all these factors are significant for adopting green products in Korea. Our results have practical implications for firms and researchers.

This study's limitations are as follows. First, we did not test the effect of various moderating variables on consumer adoption intentions. Estimating moderating variables is crucial because many potential or unknown variables affect consumer adoption of green products. Thus, future studies should take pains to examine the variables that may moderate green product adoption. 
Second, given this study's context, several factors related to green product adoption are invalid because Korean consumers are relatively indifferent to environmental concerns compared to Western consumers. Our findings indicate that environmental awareness plays an insignificant role for both product types. Increased environmental awareness among Korean consumers could reactivate other factors into the model. Future studies should focus on how environmental awareness interacts with other insignificant factors across different product types to influence consumer green product adoption. Since firms have heavily invested in eco-friendly product development and innovation [58-60], such analysis would more fully elucidate the relationship between green product adoption and firm innovation.

Finally, although this study used a binary logit model to examine gender and how consumers adopt two product types, our approach was region-specific and did not take a global perspective into account. We recommend that cross-cultural studies would be beneficial for gender differences [61,62].

Author Contributions: Conceptualization, L.-L.W. and H.-Y.H.; methodology, H.-Y.H.; software, H.-Y.H.; validation, L.-L.W. and H.-Y.H.; formal analysis, H.-Y.H.; investigation, L.-L.W.; resources, H.-Y.H.; data curation, H.-Y.H.; writing—original draft preparation, H.-Y.H.; writing-review and editing, L.-L.W.; visualization, L.-L.W.; supervision, H.-Y.H.; project administration, H.-Y.H. All authors have read and agreed to the published version of the manuscript.

Funding: This research received no external funding.

Institutional Review Board Statement: Not applicable.

Informed Consent Statement: Not applicable.

Data Availability Statement: Not applicable.

Conflicts of Interest: The authors declare no conflict of interest.

\section{Appendix A. Single-Item Measures for Each Construct}

- Environmental attitudes: "I would be willing to stop buying products when they are polluting the environment."

- Perceived consumer effectiveness: "There is not much that any one individual can do about the environment."

- Tax credits: "I expect tax benefits when I purchase green products."

- Eco-labeling: "Eco-labeling plays an important role in my purchasing decisions."

- Peer group: "Peer group opinions play a role in my decisions to purchase green products."

- Cultural values: "I expect that our emerging global protection-related cultural values will improve our ecosystems."

- Environmental awareness: "We can have an environmental impact."

- Legal enforcement: "We need more government regulations to force people to protect the global environment."

- Green advertisements: "I seldom read articles or watch TV commercials about environmental issues."

- High or increasing levels of education: "High levels of education are closely linked to positive environmental behaviors."

- Financial incentives: "I experience significant cost benefits when I purchase green products."

- Product knowledge: "How would you rate your knowledge of the product in relation to environmental issues?"

\section{References}

1. Jansson, J. Consumer eco-innovation adoption: Assessing attitudinal factors and perceived product characteristics. Bus. Strategy Environ. 2011, 20, 192-210. [CrossRef] 
2. Darko, A.; Chan, A.P.; Yang, Y.; Shan, M.; He, B.; Gou, Z. Influences of barriers, drivers, and promotion strategies on green building technology adoption in developing countries: The Ghanaian case. J. Clean. Prod. 2018, 200, 687-703. [CrossRef]

3. Kumar, R.R.; Kumar, A. Adoption of electric vehicle: A literature review and prospects for sustainability. J. Clean. Prod. 2020, 253, 1-14. [CrossRef]

4. Nath, V.; Kumar, R.; Agrawal, R.; Gautam, A.; Sharma, V. Consumer adoption of green products: Modeling the enablers. Glob. Bus. Rev. 2013, 14, 453-470. [CrossRef]

5. Hazen, B.; Wu, Y.; Cegielski, C.G.; Jones-Farmer, L.A.; Hall, D.J. Consumer reactions to the adoption of green reverse logistic. Int. Rev. Retail Distrib. Consum. Res. 2012, 22, 417-434. [CrossRef]

6. Joshi, Y.; Rahman, Z. Factors affecting green purchase behavior and future research directions. Int. Strateg. Manag. Rev. 2015, 3, 128-143. [CrossRef]

7. Nath, V.; Kumar, R.; Agrawal, R.; Gautam, A.; Sharma, V. Impediments to adoption of green products: An ISM analysis. J. Promot. Manag. 2014, 20, 501-520. [CrossRef]

8. Lin, P.; Huang, Y. The influence factors on choice behavior regarding green products based on the theory of consumption values. J. Clean. Prod. 2012, 22, 11-18. [CrossRef]

9. Kabel, D.; Elg, M.; Sundin, E. Factors influencing sustainable purchasing behavior of remanufactured robotic lawn mowers. Sustainability 2021, 13, 1954. [CrossRef]

10. Zou, L.W.; Chan, R. Why and when do consumers perform green behaviors? An examination of regulatory focus and ethical ideology. J. Bus. Res. 2019, 94, 113-127. [CrossRef]

11. Chen, C.; Chen, C.; Tung, Y. Exploring the consumer behavior of intention to purchase green products in belt and road countries: An empirical analysis. Sustainability 2018, 10, 854. [CrossRef]

12. Thøgersen, J.; Zhou, Y. Chinses consumers' adoption of a green innovation: The case of organic food. J. Mark. Manag. 2012, 28, 313-333. [CrossRef]

13. Young, W.; Hwang, K.; McDonald, S.; Oates, C.J. Sustainable consumption: Green consumer behaviour when purchasing products. Sustain. Dev. 2010, 18, 20-31. [CrossRef]

14. Chan, W.W.; Mal, L.M.; Chen, Y.M.; Wang, Y.H.; Xie, H.R.; Li, D. Energy saving and tourism sustainability: Solar control window film in hotel rooms. J. Sustain. Tour. 2008, 16, 563-574. [CrossRef]

15. Kiatkittipong, W.; Wongsuchoto, P.; Meevasana, K.; Pavasant, P. When to buy new electrical/electronic products? J. Clean. Prod. 2008, 16, 1339-1345. [CrossRef]

16. Olsen, E.L. It's not easy being green: The effects of attribute tradeoffs on green product preference and choice. J. Acad. Mark. Sci. 2013, 41, 171-184. [CrossRef]

17. Nieroda, M.E.; Mrad, M.; Solomon, M.R. How do consumers think about hybrid products? Computer wearables have an identity problem. J. Bus. Res. 2018, 89, 159-170. [CrossRef]

18. Stern, N.H.; Peters, S.; Bakhshi, V.; Bowen, A.; Cameron, C.; Catovsky, S.; Crane, D.; Cruickshank, S.; Dietz, S.; Edmonson, N. Stern Review on the Economics of Climate Change; UK Government: London, UK, 2006; p. 2.

19. Bang, H.; Ellinger, A.E.; Hadjimarcou, J.H.; Traichal, P.A. Consumer concern, knowledge, belief, and attitude toward renewable energy: An application of the reasoned action theory. Psychol. Mark. 2000, 17, 449-468. [CrossRef]

20. Persaud, A.; Schillo, S.R. Purchasing organic products: Role of social context and consumer innovativeness. Mark. Intell. Plan. 2017, 35, 130-146. [CrossRef]

21. Bhate, S.; Lawler, K. Environmentally-friendly products: Factors that influence their adoption. Technovation 1997, 17, 457-465. [CrossRef]

22. Ajzen, I. The theory of planned behavior. Organ. Behav. Hum. Decis. Process. 1991, 50, 179-211. [CrossRef]

23. Han, H.; Kim, Y. An investigation of green hotel customers' decision formation: Developing an extended of the theory of planned behavior. Int. J. Hosp. Manag. 2010, 29, 659-668. [CrossRef]

24. Lynne, G.; Rola, L. Improving attitude-behavior prediction models with economic variables: Farmer action towards soil conservation. J. Soc. Psychol. 1988, 128, 19-28. [CrossRef]

25. Ritchie, B.J.R.; McDougall, G.; Gordon, H.G.; Claxton, J.D. Complexities of household energy consumption and conservation. J. Consum. Res. 1981, 8, 233-242. [CrossRef]

26. Gerpott, T.J.; Mahmudova, I. Determinants of green electricity adoption among residential customers in Germany. Int. J. Consum. Stud. 2010, 34, 464-473. [CrossRef]

27. Ha, H.; Janda, S. Predicting consumer intentions to purchase energy-efficient products. J. Consum. Mark. 2012, 29, 461-469. [CrossRef]

28. Lai, A.W. Consumption situation and product knowledge in the adoption of a new product. Eur. J. Mark. 1991, $25,55-67$.

29. Gallagher, K.; Muehlegger, E. Giving green to get green? Incentives and consumer adoption of hybrid vehicle technology. J. Environ. Econ. Manag. 2011, 61, 1-15. [CrossRef]

30. Suki, N.M. Green product purchase intention: Impact of green brand, attitude, and knowledge. Br. Food J. 2016, 118, 2893-2910. [CrossRef]

31. Gan, C.; Wee, H.Y.; Ozanne, L.; Kao, T. Consumers' purchasing behavior towards green products in New Zealand. Innov. Mark. 2008, 4, 93-102. 
32. Maniatis, P. Investigating factors influencing consumer decision-making while choosing green products. J. Clean. Prod. 2016, 132, 215-228. [CrossRef]

33. Sreen, N.; Purbey, S.; Sadarangani, P. Impact of culture, behavior and gender on green purchase intention. J. Retail. Consum. Serv. 2018, 41, 177-189. [CrossRef]

34. Blocker, T.J.; Eckberg, D.L. Gender and environmentalism: Results from the 1993 general social survey. Soc. Sci. Q. 1997, 78, 841-858.

35. Gilligan, C. In a Different Voice; Harvard University Press: Cambridge, MA, USA, 1982.

36. Tung, T.; Koenig, H.F.; Chen, H. Effects of green self-identity and cognitive and affective involvement on patronage intention in eco-friendly apparel consumption: A gender comparison. Sustainability 2017, 9, 1-17.

37. Lee, K. Gender differences in Hong Kong adolescent consumers' green purchasing behavior. J. Consum. Mark. 2009, 26, 87-96. [CrossRef]

38. Pudaruth, S.; Juwaheer, T.; Seewoo, Y. Gender-based differences in understanding the purchasing patterns of eco-friendly cosmetics and beauty care products in Mauritius: A study of female customers. Soc. Responsab. J. 2015, 11, 179-198. [CrossRef]

39. Horowitz, J.L.; Savin, N.E. Binary response models: Logits, probits and semiparametrics. J. Econ. Perspect. 2001, 15, 43-56. [CrossRef]

40. Hill, K.; Kau, P. Analysis of purchasing decision with multivariate probit. Am. J. Agric. Econ. 1981, 53, 882-883.

41. Varotto, S.F.; Farah, H.; Toledo, T.; Arem, B.; Hoogendoorn, S.P. Modelling decision of control transitions and target speed regulations in full-range adaptive cruise control based on risk allostasis theory. Transp. Res. Part B Methodol. 2018, 117, 318-341. [CrossRef]

42. McFadden, D. The choice theory approach to market research. Mark. Sci. 1986, 5, 275-402. [CrossRef]

43. Statistic Korea. Income Trends in the First Quarter of 2019; Statistic Korea: Daejeon, Korea, 2019.

44. Ellen, P.S.; Wiener, J.L.; Cobb-Walgren, C. The role of perceived consumer effectiveness in motivating environmentally conscious behaviors. J. Public Policy Mark. 1991, 10, 102-117. [CrossRef]

45. Podsakoff, P.M.; MacKenzie, S.B.; Podsakoff, N.P.; Lee, J. Common method biases in behavioral research: A critical review of the literature and recommended remedies. J. Appl. Psychol. 2003, 88, 879-903. [CrossRef]

46. Fuchs, C.; Diamantopoulos, A. Using single item measures for construct measurement in management research. Die Betriebswirtschaft 2009, 69, 195-210.

47. Fisher, G.G.; Matthews, R.A. Developing and investigating the use of single-item measures in organizational research. J. Occup. Health Psychol. 2016, 21, 3-23. [CrossRef]

48. Regelberg, S.G.; Stanton, J.M. Introduction: Understanding and dealing with organizational survey nonresponse. Organ. Res. Methods 2007, 10, 195-209. [CrossRef]

49. Drozdenko, R.; Jensen, M.; Coelho, D. Pricing of green products: Premiums paid, consumer characteristics and incentives. Int. J. Bus. Mark. Decis. Sci. 2011, 4, 106-116.

50. Sallee, J.M. The surprising incidence of tax credits for the Toyota Prius. Am. Econ. J. Econ. Policy 2011, 3, 189-219. [CrossRef]

51. Coad, A.; Haan, P.; Woersdorfer, J.S. Consumer support for environmental policies: An application to purchases of green cars. Ecol. Econ. 2009, 68, 2078-2086. [CrossRef]

52. Schwepker, C.H.; Cornwell, T.B. An examination of ecologically concerned consumers and their intention to purchase ecologically packed products. J. Public Policy Mark. 1991, 10, 77-101. [CrossRef]

53. Wagner, S.A. Understanding Green Consumer Behavior; Routledge: London, UK, 1997.

54. Roberts, J.A. Green consumer in the 1990s: Profile and implications for advertising. J. Bus. Res. 1996, 36, 217-231. [CrossRef]

55. Straughan, R.D.; Roberts, J.A. Environmental segmentation alternatives: A look at green consumer behavior in the new millennium. J. Consum. Mark. 1999, 16, 558-575. [CrossRef]

56. Albino, V.; Balice, A.; Dangelico, R.M.; Iacobone, F.A. The effect of the adoption of environmental strategies on green product development: A study of companies on world sustainability indices. Int. J. Manag. 2012, 29, 525-538.

57. Chen, T.B.; Chai, L.T. Attitude towards the environment and green products: Consumers' perspective. Manag. Sci. Eng. 2010, 4, 27-39.

58. Huang, Y.; Yang, M.; Wong, Y. The effect of internal factors and family influence on firms' adoption of green product innovation. Manag. Res. Rev. 2016, 39, 1167-1198. [CrossRef]

59. Han, H.; Lee, K.; Radic, A.; Ngah, A.; Kim, J. The extended self-identify-based electronic product adoption model and airline business strategy: A new theoretical framework for green technology products. J. Travel Tour. Mark 2021, 38. in press. [CrossRef]

60. Zhang, J.; Liang, G.; Feng, T.; Yuan, C.; Jiang, W. Green innovation to respond to environmental regulation: How external knowledge adoption and green absorptive capacity matter? Bus. Strategy Environ. 2020, 29, 39-53. [CrossRef]

61. Ferraz, S.B.; Buhamra, C.; Laroche, M.; Veloso, A.R. Green products: A cross-cultural study of attitude, intention and purchase behavior. Resour. Entrepreneurial Dev. 2017, 18, 12-38. [CrossRef]

62. Kim, W. Advanced Regression Analysis; Wisein Publisher: Seoul, Korea, 2017. 